\title{
Weed management in soybean using burndown herbicides associated to pre-emergent herbicides
}

\author{
Carlos Orestes Santin ${ }^{1}$, Robson Peruzzo ${ }^{2}$, Leandro Galon ${ }^{1}$, André Dalponte Menegat ${ }^{1}$, Milena Barretta \\ Franceschetti ${ }^{1}$, Cinthia Maethê Holz ${ }^{1}$, Josiel Ricardo Toni ${ }^{1}$, Gismael Francisco Perin ${ }^{1}$, and César Tiago \\ Forte $^{3 *}$
}

${ }^{1}$ Universidade Federal da Fronteira Sul, Erechim, RS, Brazil. 2 Universidade do Oeste de Santa Catarina, Xanxerê, SC, Brazil.

${ }^{3}$ Universidade Federal de Santa Maria, Santa Maria, RS, Brazil. *Author for correspondence: cesartiagoforte@hotmail.com

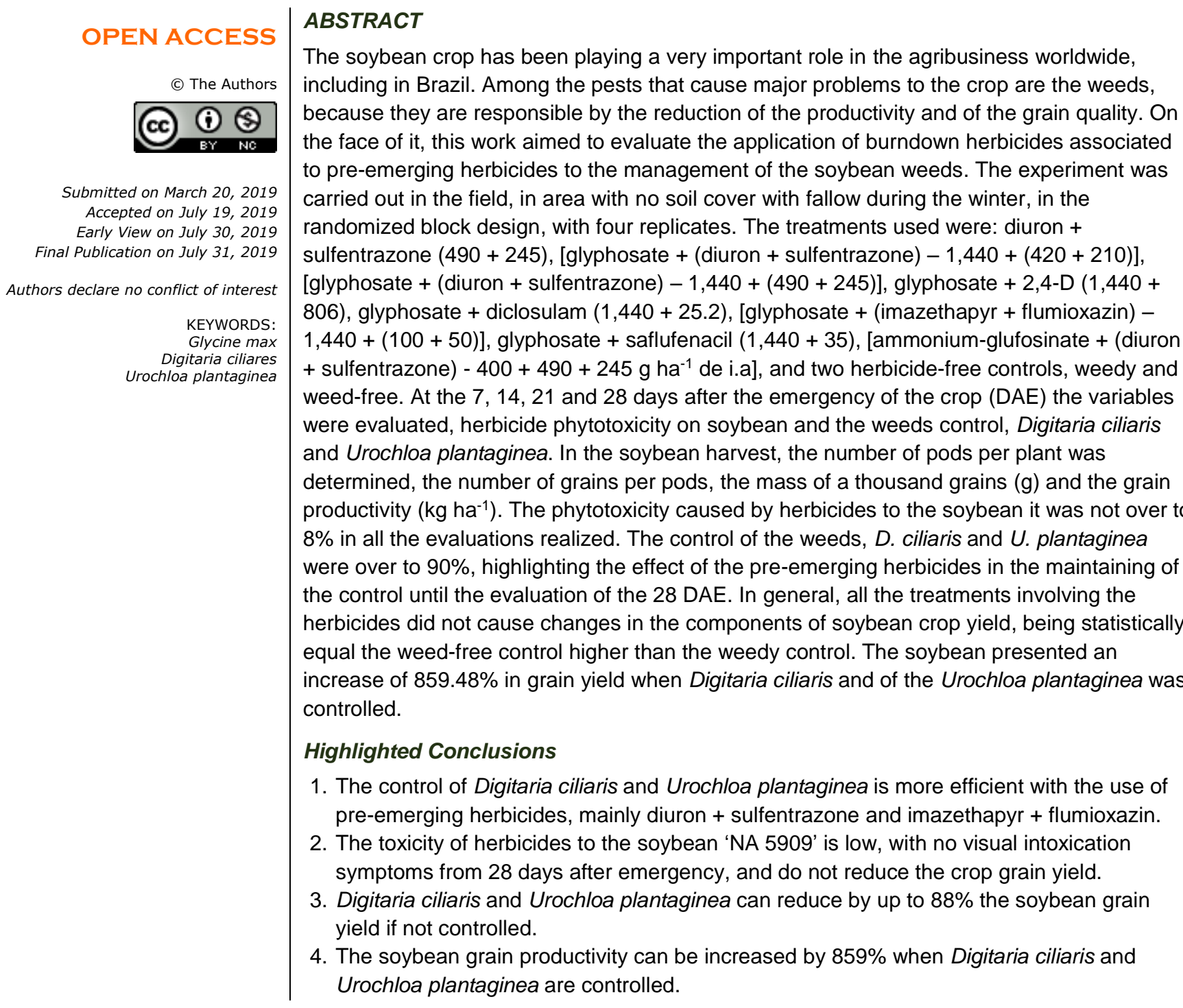

\section{INTRODUCTION}

The soybean cultivar presents an important role in the world agricultural scenario, being the oleaginous that represents a major part of production and consumption. This fact is related by its utilization as a fount of protein to the human or animal consume in the forms of oil, biodiesel and of soybean meal (Miransari 2016). In Brazil the 
soybean has a great relevance to the agribusiness, with significant increase of the cultivated area going from the limits of 21.3 million of hectares to 35.1 million in the last 10 years, besides the increase in the cultivated area, there was increase of the productivity of grains as a result of the advances in used technologies to the production (Forte et al. 2017; USDA 2018).

Currently, the problem found in soybean crops is the low efficiency in the weeds control, so that they present expressive reductions in the increase and in the development of the cultivar, as consequence occurs reduction of the grain productivity (Agostinetto et al. 2009; Forte et al. 2017; Galon et al. 2018).

According Datta et al. (2017), the presence of weeds until the critical stage of the soybean can cause reduction of 8 to $55 \%$ in productivity. Forte et al. (2017), related losses in leaf area and dry mass of the aerial part of the soybean when this was infested with Euphorbia heterophylla and Bidens pilosa because of competition that occurs by the resources light, water and nutrients in the community in which they are inserted.

Among the weeds that infest and damage the soybean crop it is highlighted the Digitaria ciliaris and the Urochloa plantaginea. The Digitaria ciliaris contends by the resources of the environment mainly in the initial stages of development of the soybean resulting in reduction of the grains productivity (Fleck et al. 2006). The Urochloa plantaginea for being a plant cespitosa forms a dense, vast and vigorous canopy with high capacity of shading the cultivar and for this presents high potential of compete with the soybean in special by the resource light (Agostinetto et al. 2009). The weeds have genetic variability which guarantees them greater adaptability, rusticity and competitiveness in the environment when compared with cultivated plants or improved by the genetic engineering (Bianchi et al. 2006).

The use of chemical control of weeds is the main tool to management in cultivar of soybean, by presenting a series of advantages in relation to the other methods of control, as: efficiency, practicality, speed in the operation, among others (Carvalho et al. 2000). The use of herbicides pre-emerging is a form of manage the weeds before that occurs the competition with the cultivars, avoiding this way, loss of productivity (Agostinetto et al. 2015). The use of these herbicides should be employed in areas that there is the knowledge of the species present in the seed bank of ground, becoming this way an effective alternative of control (Kuva et al. 2007).

The decision making for the adoption of control in pre-emergency of the weeds is a critical issue in the agricultural systems, being that the importance increases when there is increment of the cases of resistance to post-emergent herbicides (Owen et al. 2007). The association of herbicides with the glyphosate comes up alternative to improve the control and extend the useful life of this important herbicide to the cultivar of soybean (Nonemacher et al. 2017). The herbicides used in the pre-emergency of soybean present potential of control of the weeds without the cultivar suffer competition in the initial stages of development, generating this way good productivity of grains. On face of it, this work had as objective to evaluate the application of burndown herbicides associated to the pre-emergent herbicides to the management of weeds in the soybean.

\section{MATERIAL AND METHODS}

Characterization of experiment site. The experiment was conducted in field in the experimental area of the Universidade Federal da Fronteira Sul (UFFS), Campus Erechim/RS, Brazil, in the agricultural year of 2017/18, in area with no soil cover with fallow during the winter. The soil, classified as Humic Aluminoferric Red Latosol (Soil Survey Staff 2014), having as chemical and physical characteristics: $\mathrm{pH}$ in water of $4.8 ; \mathrm{MO}=3.5 \% ; \mathrm{P}=4.0 \mathrm{mg}$ $\mathrm{dm}^{-3} ; \mathrm{K}=117.0 \mathrm{mg} \mathrm{dm}^{-3} ; \mathrm{Al}^{3+}=0.6 \mathrm{cmol}_{\mathrm{c}} \mathrm{dm}^{-3} ; \mathrm{Ca}^{2+}=4.7 \mathrm{cmol}_{\mathrm{c}} \mathrm{dm}^{-3} ; \mathrm{Mg}^{2+}=1.8 \mathrm{cmol}_{\mathrm{c}} \mathrm{dm}^{-3} ; \mathrm{CTC}(\mathrm{t})=7.4 \mathrm{cmol}_{\mathrm{c}} \mathrm{dm}$ 3; $\mathrm{CTC}(\mathrm{TpH}=7.0)=16.5 \mathrm{cmol}_{\mathrm{c}} \mathrm{dm}^{-3} ; \mathrm{H}+\mathrm{Al}=9.7 \mathrm{cmol}_{\mathrm{c}} \mathrm{dm}^{-3} ; \mathrm{SB}=6.8 \mathrm{cmol}_{\mathrm{c}} \mathrm{dm}^{-3} ; \mathrm{V}=41 \%$; and Clay $=60 \%$, being that before of the seeding it was effected the correction of the fertility following the technical recommendations to the cultivar of soybean (ROLAS 2016).

The rainfall and the average daily temperature during the conduction of the experiment are presented in the Figure 1 (weather station of Erechim-RS), besides the moments of application of the treatments of herbicides in pre-emergency and the management with glyphosate at 55 DAS (days after seeding) illustrated by a yellow arrow.

Experimental design and treatments. The used experimental lineation was of randomized blocks with four repetitions. The treatments and the respective doses used in the test are disposed in the Table 1.

Each experimental unit was composed of a plot of $15 \mathrm{~m}^{2}(5 \times 3 \mathrm{~m})$, seeded with 6 rows of soybeans in the spacing of $0.5 \mathrm{~m}$, in population of 10 to 12 plants $\mathrm{m}^{-1}$, using the cultivar NA 5909. The application of the treatments was performed with a precision costal sprayer, pressurized with $\mathrm{CO}_{2}$, equipped with four fan- type spray tips DG 110.02 , maintaining constant pressure of $210 \mathrm{kPa}$ and speed of travel of $3.6 \mathrm{~km} \mathrm{~h}^{-1}$, which provided the flow of 150 $\mathrm{L} \mathrm{ha}^{-1}$ of herbicide syrup.

Plant material. To the description of the area in relation to the occurrence of weed it was performed a phytosociological survey, the counting was performed in the total area of the experiment, by counting 4 samples 
with the use of a square of $0.25 \mathrm{~m}^{2}$, the following species were identified: Digitaria ciliaris and Urochloa plantaginea in the average density of 92 and 154 plants $\mathrm{m}^{-2}$, respectively.

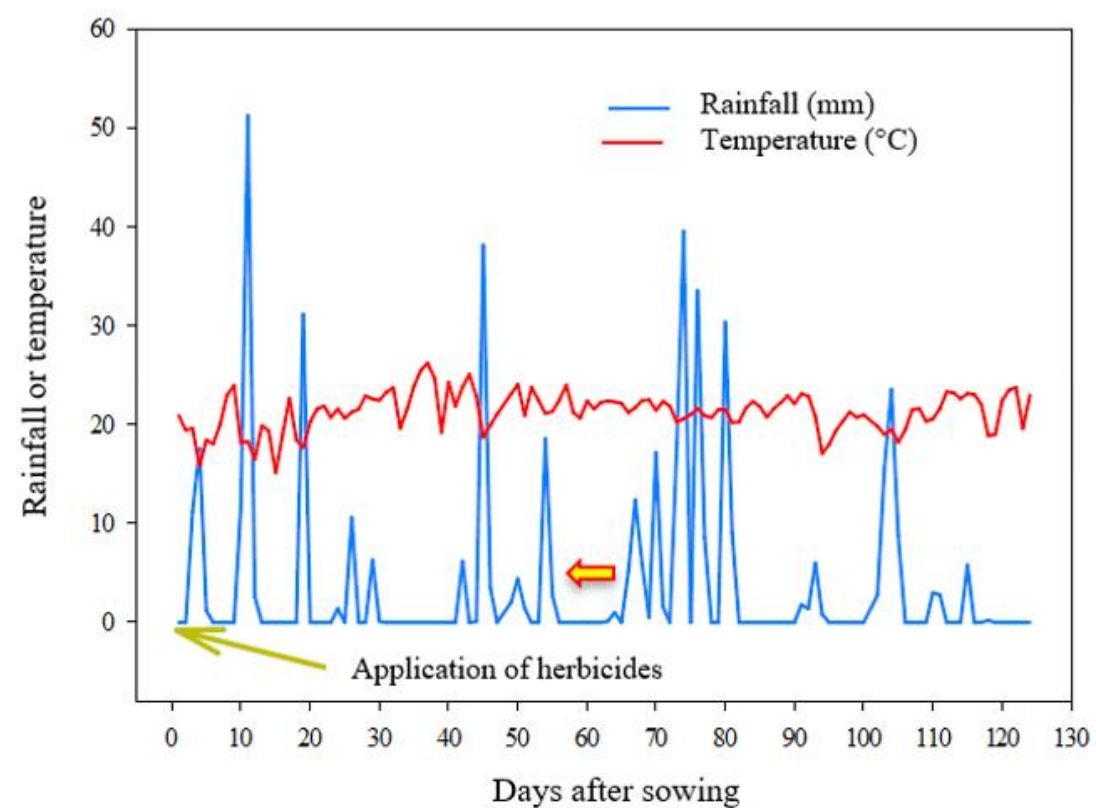

Figure 1. Rainfall $(\mathrm{mm})$ and average monthly temperature $\left({ }^{\circ} \mathrm{C}\right)$ in the soybean growing period, 124 days cycle.

Table 1. Treatments, concentration, dose of active ingredient or acid equivalent, adjuvant and time of application of herbicides.

\begin{tabular}{clcccc}
\hline $\mathrm{N}$. & Treatments $^{*}$ & $\begin{array}{c}\text { Concentration } \\
\mathrm{g} \mathrm{L}^{-1}\end{array}$ & $\begin{array}{c}\text { Dose } \\
\left(\mathrm{g} \mathrm{ha}^{-1}\right)\end{array}$ & $\begin{array}{c}\text { Dose } \\
\left(\mathrm{L} / \mathrm{kg} \mathrm{ha}^{-1}\right)\end{array}$ & Time of application \\
\hline 1 & Weedy control & $\ldots$ & $\ldots$ & $\ldots$ & $\ldots$ \\
2 & Weed-free control & $\ldots$ & $\ldots$ & $\ldots$ & $\ldots$ \\
3 & (Diuron + sulfentrazone) & $350+175$ & $490+245$ & 1.40 & Burndown \\
4 & Glyphosate & 480 & 1,440 & 3.00 & Burndown \\
& (Diuron + sulfentrazone) & $350+175$ & $420+210$ & 1.20 & Pre-emergency \\
5 & Glyphosate & 480 & 1,440 & 3.00 & Burndown \\
& (Diuron + sulfentrazone) & $350+175$ & $490+245$ & 1.40 & Pre-emergency \\
6 & Glyphosate & 480 & 1,440 & 3.00 & Burndown \\
& 2,4-D & 806 & 806 & 1.00 & Pre-emergency \\
7 & Glyphosate & 480 & 1,440 & 3.00 & Burndown \\
& Diclosulam & 840 & 25,2 & 0.03 & Pre-emergency \\
\multirow{2}{*}{8} & Glyphosate & 480 & 1,440 & 3.00 & Burndown \\
& (Imazethapyr + flumioxazin) & $200+100$ & $100+50$ & 0.50 & Pre-emergency \\
\multirow{2}{*}{9} & Glyphosate & 480 & 1,440 & 3.00 & Burndown \\
& Saflufenacil & 700 & 35 & 0.05 & Pre-emergency \\
10 & Ammonium-glufosinate & 200 & 400 & 2.00 & Burndown \\
& (Diuron + sulfentrazone) & $350+175$ & $490+245$ & 1.40 & Pre-emergency \\
\hline
\end{tabular}

${ }^{*}$ To all the herbicide treatments were used the adjuvant Assist in $0.5 \% \mathrm{v} / \mathrm{v}$.

Variables measured. At the 7, 14, 21 and 28 days after the emergency of the cultivar (DAE) it was evaluated the phytotoxicity in the soybean and the control of the weeds caused by the herbicides. It is attributed percentage marks, in which zero $(0 \%)$ represented absence of phytotoxicity to the soybean or of control of weeds and the mark of one hundred $(100 \%)$ to the complete death of the culture or of the weeds, according with the proposed methodology by SBCPD (1995). At the 55 DAE it was applied glyphosate $\left(1,440 \mathrm{~g} \mathrm{ha}^{-1}\right)$, except in the controls, to control the weed species present in the plots in which were not found by the application of the treatments and this way avoid the competition.

In the pre-harvest of soybean were evaluated the variables: number of pods per plant (NVP) and number of grains per plant (NGP) in five plants collected in aleatory mode in each experimental unit. The harvest of soybean 
was realized when the grains reached $16 \%$ of moisture, in useful area of $6.0 \mathrm{~m}^{2}$ by experimental unit, after taking the trail. To further determine the mass of one thousand grains (g) (MMG), were contacted 8 samples of 100 grains each one and weigh in analytical balance, after achievement of average was extrapolated to MMG. To the analyses, the grain moisture was adjusted to $13 \%$ (through calculations) and the data of productivity of grains (PROD) extrapolated to $\mathrm{kg} \mathrm{ha}^{-1}$.

Statistical analysis. The data were submitted to the analysis of variance by the test $F$, and, in being significant, the averages were submitted to the test of Scott-Knott using $p \leq 0,05$.

\section{RESULTS AND DISCUSSION}

There were significant effects of the treatments only to the phytotoxicity evaluated at 7, 14 and 21 DAE (Table 2), in all the evaluations of control of Digitaria ciliaris (Table 3) and of Urochloa plantaginea (Table 4) and in the variables related to the income components - number of pods per plant - NVP, number of grains per pods - NGP and to the productivity of grains - PROD (Table 5).

Table 2. Intoxication (\%) of the soybean cultivar NA 5909 by the use of herbicide associations applied in the pre-emergency of the cultivar.

\begin{tabular}{lccccc}
\hline & \multirow{2}{*}{$\begin{array}{c}\text { Dose } \\
\text { Treatment }\end{array}$} & $\left(\mathrm{g} \mathrm{ha}^{-1}\right)$ & \multicolumn{3}{c}{ Intoxication (\%) } \\
\cline { 3 - 5 } & & $7 \mathrm{DAE}^{1}$ & $14 \mathrm{DAE}$ & $21 \mathrm{DAE}$ & $28 \mathrm{DAE}$ \\
\hline Weedy control & --- & $0 \mathrm{~b}^{2}$ & $0 \mathrm{~b}$ & $0 \mathrm{~b}$ & $0^{\text {ns }}$ \\
Weed-free control & - & $0 \mathrm{~b}$ & $0 \mathrm{~b}$ & $0 \mathrm{~b}$ & 0 \\
Diuron+sulfentrazone & $490+245$ & $7 \mathrm{a}$ & $3 \mathrm{a}$ & $6 \mathrm{a}$ & 0 \\
Glyphosate+(diuron+sulfentrazone) & $1,440+(420+210)$ & $6 \mathrm{a}$ & $2 \mathrm{a}$ & $7 \mathrm{a}$ & 0 \\
Glyphosate+(diuron+sulfentrazone) & $1,440+(490+245)$ & $8 \mathrm{a}$ & $3 \mathrm{a}$ & $6 \mathrm{a}$ & 0 \\
Glyphosate+2,4-D & $1,440+806$ & $0 \mathrm{~b}$ & $0 \mathrm{~b}$ & $6 \mathrm{a}$ & 0 \\
Glyphosate+diclosulam & $1,440+25,2$ & $5 \mathrm{a}$ & $3 \mathrm{a}$ & $5 \mathrm{a}$ & 0 \\
Glyphosate+(imazethapyr+flumioxazin) & $1,440+(100+50)$ & $6 \mathrm{a}$ & $3 \mathrm{a}$ & $5 \mathrm{a}$ & 0 \\
Glyphosate+saflufenacil & $1,440+35$ & $0 \mathrm{~b}$ & $0 \mathrm{~b}$ & $0 \mathrm{~b}$ & 0 \\
Ammonium-glufosinate+(diuron+sulfentrazone) & $400+(490+245)$ & $5 \mathrm{a}$ & $4 \mathrm{a}$ & $0 \mathrm{~b}$ & 0 \\
\hline C.V (\%) & ---- & 44.86 & 43.94 & 40.61 & 0.00 \\
\hline
\end{tabular}

${ }^{1}$ Days after the emergency. ${ }^{2}$ Averages followed by the same letters in the columns do not differ between each other by the Scott-Knott test in $\mathrm{p} \leq 0.05$. ${ }^{\text {ns }}$ do not significant.

The results show that the phytotoxicities to the soybean were lower than $8 \%$, being considered low and it was observed some injury of the herbicides until the $21 \mathrm{DAE}$, after that the culture recovered of the symptoms of damage (Table 2). The treatments with glyphosate + (diuron + sulfentrazone), glyphosate + diclosulam e glyphosate + imazethapyr + flumioxazin, the association of ammonium-glufosinate + diuron + sulfentrazone and the application of diuron + sulfentrazone in isolated, presented the higher symptoms of phytotoxicity in all the evaluations made. The use of glyphosate associated to pre-emerging herbicides with residual in soybean also caused low phytotoxicity to the cultivar ND 5445 IPRO (Nonemacher et al. 2017), what corroborate with the results found in this study.

At the 28 DAE were not observed visual symptoms of toxicity in the culture of soybean (Table 2), showing this way, that the associations of the herbicides are quickly metabolized by the plants. Studies conducted by Kandel et al. (2018) also show that associations using sulfentrazone, saflufenacil, flumioxazin do not present symptoms of phytotoxicity until the stadium V4 of the culture of the soybean.

The application of glyphosate + imazethapyr + flumioxazin present lower control when compared to other treatments at the $7 \mathrm{DAE}$, with the exception of glyphosate +2,4-D and glyphosate + diclosulam, however at the 28 DAE this was the herbicide treatment that presented the best control of Digitaria ciliaris (85\%) and $80 \%$ of control of Urochloa plantaginea, only lower than the weed-free control (Table 3 and 4). The use of imazethapyr caused low control of $D$. ciliaris, due to the morphological characteristics of the species (López-Ovejero et al. 2013). Galon et 
al. (2017), assessing the efficiency of flumioxazin to the control of $D$. ciliaris found low control (30\%) at the 7 DAA, do not being efficient in the posterior evaluations. The efficiency of these two active principles is proven used to the control of weeds of broad leaves (flumioxazin) and narrow (imazethapyr) in pre-emergency and its high residual period (Oliveira et al. 2001; Grichar et al. 2009), this way the results obtained in the evaluation of the 28 DAA in the present study proves the efficiency to the monocotyledons weeds. This way, the association of this is a great alternative to the management of the weeds of the soybean when known the bank of ground seeds.

Table 3. Control (\%) of Digitaria ciliaris in soybean cultivation NA 5909 in function of the application of herbicide associations in the pre- and post-emergency.

\begin{tabular}{|c|c|c|c|c|c|}
\hline \multirow{2}{*}{ Treatments } & \multirow{2}{*}{$\begin{array}{l}\text { Dose } \\
\left(\mathrm{g} \mathrm{ha}^{-1}\right)\end{array}$} & \multicolumn{4}{|c|}{ Control of Digitaria ciliaris (\%) } \\
\hline & & $07 \mathrm{DAE}^{1}$ & $14 \mathrm{DAE}$ & $21 \mathrm{DAE}$ & $28 \mathrm{DAE}$ \\
\hline Weedy control & --- & $0 c^{2}$ & $0 d$ & $0 \mathrm{c}$ & $0 \mathrm{e}$ \\
\hline Weed-free control & --- & $100 \mathrm{a}$ & $100 \mathrm{a}$ & $100 \mathrm{a}$ & $100 \mathrm{a}$ \\
\hline Diuron+sulfentrazone & $490+245$ & $95 \mathrm{a}$ & $90 \mathrm{~b}$ & $75 \mathrm{~b}$ & $73 c$ \\
\hline Glyphosate+(diuron+sulfentrazone) & $1,440+(420+210)$ & $96 \mathrm{a}$ & $90 \mathrm{~b}$ & $73 \mathrm{~b}$ & $73 c$ \\
\hline Glyphosate+(diuron+sulfentrazone) & $1,440+(490+245)$ & $93 \mathrm{a}$ & $90 \mathrm{~b}$ & $74 \mathrm{~b}$ & $70 \mathrm{c}$ \\
\hline Glyphosate+2,4-D & $1,440+806$ & $0 \mathrm{c}$ & $0 \mathrm{~d}$ & $0 \mathrm{c}$ & $0 \mathrm{e}$ \\
\hline Glyphosate+diclosulam & $1,440+25,2$ & $0 \mathrm{c}$ & $40 \mathrm{c}$ & $82 \mathrm{~b}$ & $65 c$ \\
\hline Glyphosate+(imazethapyr+flumioxazin) & $1,440+(100+50)$ & $85 b$ & $88 \mathrm{~b}$ & $74 \mathrm{~b}$ & $85 b$ \\
\hline Glyphosate+saflufenacil & $1,440+35$ & $0 \mathrm{c}$ & $0 d$ & $0 \mathrm{c}$ & $0 \mathrm{e}$ \\
\hline Ammonium-glufosinate $+($ diuron+sulfetrazone $)$ & $400+(490+245)$ & $88 \mathrm{~b}$ & $89 \mathrm{~b}$ & $75 b$ & $50 \mathrm{~d}$ \\
\hline C.V (\%) & --- & 10.54 & 8.09 & 22.96 & 15.96 \\
\hline
\end{tabular}

Table 4. Control (\%) of Urochloa plantaginea in soybean cultivation NA 5909 in function of application of herbicide associations in the pre- and post-emergency.

\begin{tabular}{|c|c|c|c|c|c|}
\hline \multirow{2}{*}{ Treatments } & \multirow{2}{*}{$\begin{array}{l}\text { Dose } \\
\left(\mathrm{g} \mathrm{ha}^{-1}\right)\end{array}$} & \multicolumn{4}{|c|}{ Control of Urochloa plantaginea (\%) } \\
\hline & & $07 \mathrm{DAE}^{1}$ & $14 \mathrm{DAE}$ & $21 \mathrm{DAE}$ & $28 \mathrm{DAE}$ \\
\hline Weed-free control & --- & $100 \mathrm{a}$ & $100 \mathrm{a}$ & $100 \mathrm{a}$ & $100 \mathrm{a}$ \\
\hline Glyphosate+(diuron+sulfentrazone) & $1,440+(420+210)$ & 99 a & $90 \mathrm{~b}$ & $81 \mathrm{~b}$ & $83 \mathrm{~b}$ \\
\hline Glyphosate+(diuron+sulfentrazone) & $1,440+(490+245)$ & 99 a & $91 \mathrm{~b}$ & $79 \mathrm{~b}$ & $76 \mathrm{~b}$ \\
\hline Glyphosate+2,4-D & $1,440+806$ & $0 \mathrm{c}$ & $0 \mathrm{~d}$ & $0 \mathrm{c}$ & $0 \mathrm{c}$ \\
\hline Glyphosate+(imazethapyr+flumioxazin) & $1,440+(100+50)$ & $88 \mathrm{~b}$ & $85 b$ & $74 \mathrm{~b}$ & $80 \mathrm{~b}$ \\
\hline Glyphosate+ saflufenacil & $1,440+35$ & $0 \mathrm{c}$ & $0 \mathrm{~d}$ & $0 \mathrm{c}$ & $0 \mathrm{c}$ \\
\hline Ammonium - glufosinate +(diuron+sulfetrazone) & $400+(490+245)$ & 99 a & $88 \mathrm{~b}$ & $92 \mathrm{~b}$ & $74 b$ \\
\hline C.V (\%) & --- & 10.64 & 5.94 & 15.75 & 21.35 \\
\hline
\end{tabular}

The association of glyphosate with (diuron + sulfentrazone) independent of the applied dose presented satisfactory control of $U$. plantaginea (Table 4). The association of glyphosate + sulfentrazone ( $\left.245 \mathrm{~g} \mathrm{of} \mathrm{i.a} \mathrm{ha}^{-1}\right)$ 
applied in post-emergency of the soybean provided superior control over $85 \%$ of $U$. plantaginea and $D$. ciliaris until the 14 DAA, result that characterizes the sulfentrazone as herbicide that maintains residual effect to these two species of weeds (Nonemacher et al. 2017).

Table 5. Components of grain yield of soybean cultivar NA 5909 in function of the application of herbicide associations in the pre- and post-emergency of the cultivar.

\begin{tabular}{|c|c|c|c|c|c|}
\hline Treatments & Dose & NVP & NGP & MMG & PROD \\
\hline Weedy control & --- & $25.1 \mathrm{~b}$ & $56.4 \mathrm{c}$ & $167.2^{\mathrm{ns}}$ & $459.0 \mathrm{~b}$ \\
\hline Weed-free control & --- & $63.0 \mathrm{a}$ & $151.4 \mathrm{a}$ & 167.0 & $3,884.9 \mathrm{a}$ \\
\hline Diuron+sulfentrazone & $490+245$ & $54.3 \mathrm{a}$ & $176.3 \mathrm{a}$ & 164.4 & $3,984.9 \mathrm{a}$ \\
\hline Glyphosate+(diuron+sulfentrazone) & $1,440+(420+210)$ & $57.1 \mathrm{a}$ & $127.7 b$ & 179.4 & $3,791.1 \mathrm{a}$ \\
\hline Glyphosate+(diuron+sulfentrazone) & $1,440+(490+245)$ & $58.6 \mathrm{a}$ & $127.9 b$ & 167.2 & $3,868.1 \mathrm{a}$ \\
\hline Glyphosate+2,4-D & $1,440+806$ & $66.9 \mathrm{a}$ & $132.0 \mathrm{~b}$ & 163.1 & $3,921.6 \mathrm{a}$ \\
\hline Glyphosate+diclosulam & $1,440+25,2$ & $62.2 \mathrm{a}$ & $126.5 b$ & 179.6 & $4,054.7 \mathrm{a}$ \\
\hline Glyphosate+(imazethapyr+flumioxazin) & $1,440+(100+50)$ & $60.8 \mathrm{a}$ & $170.4 \mathrm{a}$ & 177.2 & $4,120.9 \mathrm{a}$ \\
\hline Glyphosate+saflufenacil & $1,440+35$ & $58.1 \mathrm{a}$ & $175.9 \mathrm{a}$ & 164.9 & $3,967.1 \mathrm{a}$ \\
\hline Ammonium - glufosinate + (diuron+sulfetrazone) & $400+(490+245)$ & $63.7 \mathrm{a}$ & $170.4 \mathrm{a}$ & 174.8 & $3,911.8 \mathrm{a}$ \\
\hline C.V $(\%)$ & --- & 17.43 & 14.53 & 6.19 & 9.00 \\
\hline
\end{tabular}

The results show that the ammonium-glufosinate associated with (diuron + sulfentrazone) presented great control of $U$. plantaginea until the $7 \mathrm{DAE}$, similar to the weed-free control (Table 4). Starting from the 7 until the 21 DAE this treatment kept with good control of the weed, superior than $88 \%$, what is considered suitable, because to present good efficiency the literature indicates to have control superior than $80 \%$ (Oliveira et al. 2009). According to Brunharo et al. (2014) the interaction between herbicides pre-emerging and post-emergent can result in more effective control of the weeds in annual or perennial cultures. The treatment of glyphosate + diuron + sulfentrazone did not differ from the treatment ammonium-glufosinate + diuron + sulfentrazone in all the evaluations of control of $U$. plantaginea. This way the ammonium-glufosinate can substitute the glyphosate in the management of weeds, in view of the increase of the cases of resistance in function of the use of the glyphosate in the world (Westwood et al. 2018).

The application of diuron + sulfentrazone presented satisfactory control of $D$. ciliaris and of $U$. plantaginea until the 14 DAE (Tables 3 and 4), possibly by the residual of the sulfentrazone (Norsworthy 2004). The use of the association of chlorimuron + sulfentrazone made possible a control over $90 \%$ of weeds, emphasizing the residual effect of sulfentrazone, because chlorimuron do not have a significant residual effect (Norsworthy 2004). To glyphosate + diuron + sulfentrazone $\left(1,440+420+210 \mathrm{~g}^{\text {i.a }}\right.$ ha $\left.^{-1}\right)$ the control of $U$. plantaginea was of $81 \%$ and $83 \%$, to 21 and $28 \mathrm{DAE}$, respectively.

For yield components NVP and NGP it was observed difference between the treatments, however did not impacted in the MMG and PROD (Table 5), except for the weedy control, that presented the worst results to all these variables (Table 5). The competitiveness of the weeds significantly decreased the NVP and the NGP, variables these ones that were decisive to the decrease of the productivity of grains of soybean in the weedy control.

The herbicide 2,4-D, even though does not be a graminicide, did not present decrease of the productivity of grains of soybean, effect this one that can be linked to the environmental conditions (high rainfall and high temperatures) shown in the Figure 1, and also by the control of the weeds in stadium V4, where was made the application of glyphosate in complete area, managing the weeds that left of the treatments.

With the association of the tested herbicides in this work it was possible to observed that did not occur difference in the productivity of grains among the treatments, being observed the difference only in relation to the weedy control (Table 5), where was not realized any control method of weeds. In this case the loss of productivity of grains would 
be next to $88 \%$, showing the competitive capacity of the weeds $D$. ciliaris and $U$. plantaginea when infesting the culture of soybean. The soybean presented increment of $859.48 \%$ in the productivity of grains when comparing the weedy control with some form of control (weeding or use of herbicides) of the D. ciliaris and U. plantaginea. A possible contribution to the more efficient control of weeds can be related to the use of pre-emerging herbicides, since the use of two or more mechanisms of action can contribute to both for control and for decrease of the cases of resistance of weeds (López-Ovejero et al. 2013).

In general, the use of pre-emergent herbicides made possible the low phytotoxicity in the culture of the soybean (Table 2), extended control of the weeds $D$. ciliaris and $U$. plantaginea (Tables 3 and 4 ) and the no interference in the income components of grains of soybean cultivar NA 5909 (Table 5). Nonemacher et al., (2017) when evaluating the effect of the glyphosate associated to residual herbicides on the cultivar of soybean ND 5445 IPRO also verified that the residual effect increased the control of weeds and with this occurred a better productivity of grains of the culture. Currently, the chemical control shows to be the most efficient, but researches indicate that the integrated management tends to be the tool which will make possible the better and most sustainable technique of control in the future generations (Westwood et al. 2018).

\section{Acknowledgments}

The authors thank the Conselho Nacional de Desenvolvimento Científico e Tecnológico (CNPq) and the Fundação de Amparo à Pesquisa do Rio Grande do Sul (FAPERGS), for granting scholarships and financial assistance for the work development.

\section{References}

Agostinetto D et al. 2009. relative competitiveness of soybean in simultaneous growth with alexandergrass (Brachiaria plantaginea). Scientia Agraria 10:185-190.

Agostinetto D et al. 2015. Soja: do plantio a colheita. In: Sediyama T et al. (Eds.). Manejo de plantas daninhas. Viçosa: Editora UFV. pp.234255.

Bianchi MA et al. 2006. Proportion among soybean and competitor plants and the relations of mutual interference. Ciência Rural 36:380-1387.

Brunharo CAG et al. 2014. Aspectos do mecanismo de ação do amônio-glufosinato: culturas resistentes e resistência de plantas daninhas.

Revista Brasileira de Herbicidas 13:163-177.

Carvalho FT et al. 2000. Eficácia de herbicidas no manejo de plantas daninhas para o plantio direto de soja. Revista Brasileira de Herbicidas 1:167-172.

Datta A. et al. 2017. Managing weeds using crop competition in soybean [Glycine max (L.) Merr.]. Crop Protection 95:60-68.

Fleck NG et al. 2006. Interferência de Raphanus sativus sobre cultivares de soja durante a fase vegetativa de desenvolvimento da cultura. Planta Daninha 24:425-434.

Forte CT et al. 2017.Competitive ability of transgenic soybean cultivars coexisting with weeds. Revista Brasileira de Ciências Agrárias 12:185193.

Galon L. et al. 2017. Associação de herbicidas para o controle de plantas daninhas em feijão do tipo preto. Revista Brasileira de Herbicidas 16:268-278.

Galon L et al. 2018. Competitive interaction between commom black bean cultivars and Euphorbia heterophylla. Pesquisa Agropecuária Tropical 48:254-260.

Grichar J et al. 2009. Sesame (Sesamum indicum L.) response to preemergence herbicides. Crop Protection 28:928-933.

Kandel $Y$ et al. 2018. Impact of fluopyram fungicide and preemergence herbicides on soybean injury, population, sudden death syndrome, and yield. Crop Protection 106:103-109.

Kuva MA et al. 2007. Fitossociologia de comunidades de plantas daninhas em agroecossistema cana-crua. Planta Daninha 25:501-511.

López-Ovejero RF et al. 2013. Herbicidas residuais no manejo de plantas daninhas para soja resistente ao glyphosate no Brasil. Planta Daninha 31:947-959.

Miransari M. 2016. Soybean, protein, and oil production under stress. In: Miransari M (Ed). Environmental stresses in soybean production. AbtinBerkeh Scientific Ltd. Company: Isfahan. pp.157-176.

Nonemacher F et al. 2017. Associação de herbicidas aplicados para o controle de plantas daninhas em soja resistente ao glyphosate. Revista Brasileira de Herbicidas 16:152-162.

Norsworthy JK. 2004. Broadleaved weed control in wide-row soybean (Glycine max) using conventional and glyphosate herbicide programmes. Crop Protection 23:1229-1235.

Oliveira AR et al. 2009. Controle de Commelina benghalensis, C. erecta, Tripogandra diuretica na cultura do café. Planta Daninha 27:823-830.

Oliveira $V$ et al. 2001. Substitution of corn by coffee hulls in isoenergetic diets for growing and finishing pigs: digestibility and performance. Ciência e Agrotecnologia 25:424-436.

Owen $\mathrm{M}$ et al. 2007. Widespread occurrence of multiple herbicide resistance in Western Australian annual ryegrass (Lolium rigidum) populations. Australian Journal of Agricultural Research 58:711-718.

ROLAS - Rede Oficial de Laboratórios de Análise de Solo e de Tecido Vegetal. 2016. Manual de adubação e calagem para os estados do Rio Grande do Sul e Santa Catarina, Porto Alegre: Sociedade Brasileira de Ciência do Solo, 11, 376p.

SBCPD - Sociedade Brasileira da Ciência das Plantas Daninhas. 1995. Procedimentos para instalação, avaliação e análise de experimentos com herbicidas. SBCPD: Londrina.

Soil Survey Staff. 2014. Keys to Soil Taxonomy. USDA: Washington.

USDA. 2018. Foreign Agricultural Service: World Soybean Production, Consumption, and Stocks. Available at:<https://apps.fas.usda.gov>. Accessed on Jan 16, 2019.

Westwood JH et al. 2018. weed management in 2050: perspectives on the future of Weed Science. Weed Science 66:275-285. 